\title{
Using Nigella sativa Oil to Treat and Heal Chemical Induced Wound of Rabbit Skin
}

\author{
Osama A. Abu-Zinadah \\ Dept. of Biological Sciences, Faculty of Science, \\ King Abdulaziz Univ., Jeddah, Saudi Arabia
}

\begin{abstract}
The aim of this study is to evaluate the efficacy of Nigella sativa oil (NSO) to accelerate the repairing of wound healing in burn wound model using local rabbits as experimental animals. Premature rabbits are chemically burned by concentrated $\mathrm{HCl}$, and then they divided into three groups, control and topically treated ones ( 5 animals each). One of the treated groups was topically treated by antibiotic (Baneocin), while the other was treated by NSO. The contracting ability was evaluated by the reducing width of wounds daily. It was observed that the contracting ability of the wounds treated by (NSO) is similar to that of the antibiotic. However, there was somewhat retardation in wound treated with NSO. The closure time of the wounds of both was more or less similar. However, the hair growing time was the same in both treated groups. Histologically, the peripheries of the wounds grow rapidly in treated groups without any contamination by microbes. The present results support the use of such NSO in topical skin care and healing wounds.
\end{abstract}

\section{Introduction}

Black Cumin, Nigella sativa (NS) has been used as a natural healing aid for thousands of years by various cultures and civilizations around the world, as well as a supplement to help maintaining good health. It is most famous for the saying of the holy prophet Muhammad P.B.U.H. "Hold on to use of the Black seed, for it has a remedy for every illness except death." The word "hold on to" indicates a long term use.

The seeds of NS (Ranunculaceae) are commonly used in folk (herbal) medicine all over the world for treatment and prevention of a number of skin diseases and conditions ${ }^{[1 \& 2]}$ The seeds contain both fixed 
and essential oils, proteins, alkaloids and saponins ${ }^{[3 \& 4]}$. Much of the biological activities of the seeds have been shown to be due to the thymoquinone, in which the major component of the essential oils and volatile oil, that have been reported include protection against neuro and hepatotoxicity induced by either disease or chemicals ${ }^{[1]}$. It would appear that the beneficial effects of the use of seeds and thymoquinone might be related to their cytoprotective and antioxidant actions, and to their effect on some mediator of inflammation ${ }^{[5]}$.

El-Kadi and Kandil (1986) ${ }^{[6]}$ investigated the effect of NS on immune system and reported that the administration of $1 \mathrm{~g}$ twice daily in human volunteers enhanced immune functions as manifested by improve helper $\mathrm{T}$ cells and natural killer cell activity. However, Fararh ${ }^{[7]}$ demonstrated that NS seeds and its purified proteins enhanced the production of interleukin-3 by human lymphocytes and have an effect on macrophages as well. In other study Hanafi ${ }^{[8]}$ observed that NS promote stimulatory and suppressive effects depending upon the donor and concentration used. In the same root of study, it was reported that the ethanolic extract of Nigella sativa has been shown to potentiate cellular immune responses ${ }^{[9]}$.

Plant extracts and their oils were used to improve wound healing in burn-wound model, such as Celosia argentea extract which accelerated the wound closure and promoted cell motility and proliferation of primary dermal fibroblasts and keratocytes ${ }^{[10]}$. Plants of genus Ranunculus were also used to treat ulcers, sores, scab and some types of burns $^{[11]}$.

Many plant extracts have antibacterial effect on Staphylococcus aureus, Streptococcus pyogenes and Candida albicans by inhibiting both proliferation of bacteria and inflammation caused by antigen. Furthermore, it was suggested that the use of such extracts as medicinal drugs, which affectively moisten (Tran epidermal water), prevent and heal dermatitis ${ }^{[12,13]}$, reported that NS extracts had antibacterial effect on gram positive (Staphylococcus aureus) and gram Negative (Pseudomonas aerogenosa and Escherichia coli) in concentration dependent manner. Crude extracts of NS were also found to have a promising effect on multi antibiotic resistant organisms ${ }^{[14]}$. NS and some of its active principles, thymoquinone, had been shown to possess 
protective effect against hematological, hepatic, renal and other toxicities induced by anticancer drugs and some toxins ${ }^{[15]}$. The moquinones of the fixed oils were also inhibit non enzymatic peroxidation in brain phospholipid lysosomes ${ }^{[16,17]}$. Burits ${ }^{[3]}$ found the essential oil and its constituents to have antioxidant effect on different chemical assays and $\mathrm{OH}$ radical scavenging property for non-enzymatic lipid peroxidation in liposomes and the deox-ribose degradation. Mabrouk et al. ${ }^{[18]}$ studied the protective effect of bee honey and NS seeds on the oxidative stress and carcinogenesis induced by methylnitrosourea (MNU) in rats. The results suggested that supplementation of diet with honey and NS protects from such stresses. Regarding the mode of action of NSO, it was found that such oil modulated the fibrolytic potential of fibrosarcoma cell-line and elucidated that the oil might be used as anti-tumor and imply the inhibition of local tumor invasion and metastasis ${ }^{[19]}$.

The present study aim is to test the possibility of using NSO to treat burn wounds and repair chemically induced burns of rabbit skin.

\section{Materials and Methods}

\section{Experimental Animals}

Premature rabbits (local) were obtained from private farm in Jeddah, Saudi Arabia. Their average weights were 0.5-0.75 kg. They were acclimatized for one week in stainless steel cages and fed commercial diets, vegetables, crushed wheat and corn all over the whole experiment. They were divided into three groups ( 5 animals each), one control and two experimental groups. The skins of all animals were burned with conc. HCl. The two experimental groups were treated with NSO or antibiotic.

\section{Induction of Burns}

The skin of rabbits were shaved mechanically and leaved for $24 \mathrm{~h}$, two or three drops of concentrated $\mathrm{HCl}(80 \%)$ were topically put carefully on the shaved skin. Then the skin burned rabbits were housed separately under sterile conditions in isolated room cleaned with sterile solution. 


\section{Topical Application of Treatments}

The two experimental groups were treated twice daily by the treatment materials. One of these groups treated by NSO, while the other by antibiotic known as Baneocin zinc. The NSO was a product of Esmail, A., Squeezing Co., Jeddah, Saudi Arabia, while the antibiotic was produced by Pharco Pharmaceuticals, Egypt, under the license of Biochemie $\mathrm{GmbH}$, Vienna Austria. The active ingredients were Bacitracin zinc $250 \mathrm{IU} / \mathrm{gm}$, and Neomycin (as sulphate) $500 \mathrm{IU} / \mathrm{gm}$.

\section{Observations of Burns}

The areas of the burns were recorded daily to show the contracting ability of wounds and to determine the closure time. The granulations of tissues or rebuilt layers were observed and how the contamination of wounds was also observed. The hair growing time was recorded.

The contracting ability of burns was measured by drawing the wound. This was carried out by putting clean filter paper on the wound and on other paper. The wound shape was drowning as stamped upon the filter paper. The drown wound shape was smoothly cut and weighted.

Statistical student T-test was applied to measure the significant difference between the volumes of wounds of the control and treated groups.

\section{The Contracting Ability and the Closure Time}

The contracting ability can be defined as the ability of the wound to become narrower than the beginning volume; throughout the observation of the periphery around the wound. The closure time is the time where the burn-wound looks like normal appearance. The growing hair time is the time where the hairs can be seen on the epidermis.

\section{Results}

\section{Contracting Ability}

The burn wounds were irregular in shape and depth. However, the control group wounds were expanded and covered by white greenish or white yellowish layer of infection. By time the wounds were severely 
inflammated and became deeper and wider at the third week of experimentation. The averages were $5.12-9.72 \mathrm{~cm}^{2}$ and $5.75-11.13 \mathrm{~cm}^{2}$ at the first and third week respectively (Table 1). At the end of the fourth week some of the wounds became rough and covered by thick hard material (Fig. 1\&2) without any repairing of skin architecture or hair growing. Thus the closure time was not easy to determine in some wounds. However, the closure time was between 25 to 28 days.

Table 1. Effect of topical application of treatments on the induced skin burnwounds of rabbit.

\begin{tabular}{|c|c|c|c|c|c|c|}
\hline \multirow{2}{*}{\multicolumn{2}{|c|}{ Experimental groups }} & \multicolumn{5}{|c|}{ Average of the wound area $\left(\mathrm{cm}^{2}\right)$} \\
\hline & & \multicolumn{5}{|c|}{ Experimental times (weeks) } \\
\hline$\cong$ & & 1 & 2 & 3 & 4 & 5 \\
\hline 茄 & $\begin{array}{l}\text { Mean } \pm \text { S.D. } \\
\text { Closure time }\end{array}$ & $\begin{array}{l}5.12-9.72 \\
7.45 \pm 0.35\end{array}$ & $\begin{array}{l}5.06-7.51 \\
6.27 \pm 0.56\end{array}$ & $\begin{array}{c}5.75-11.13 \\
8.46 \pm 0.41\end{array}$ & $\begin{array}{c}5.04-9.75 \\
7.41 \pm 0.42 \\
\text { Day } 26\end{array}$ & $\begin{array}{c}4.42-7.12 \\
5.77 \pm 0.29 \\
\text { Day } 33\end{array}$ \\
\hline 总 & $\begin{array}{c}\text { Average } \\
\text { Mean } \pm \text { S.D. } \\
\text { Closure time }\end{array}$ & $\begin{array}{l}3.78-7.02 \\
5.41 \pm 0.48\end{array}$ & $\begin{array}{c}2.52-5.20 \\
3.88 \pm 0.38^{* *} \\
\text { Day } 18\end{array}$ & $\begin{array}{c}1.71-2.43 \\
2.11 \pm 0.31^{* *} \\
\quad \text { Day } 22\end{array}$ & $\begin{array}{c}0.83-1.63 \\
1.21 \pm 0.28^{*}\end{array}$ & $\begin{array}{c}0.31-0.80 \\
0.61 \pm 0.21^{* *}\end{array}$ \\
\hline 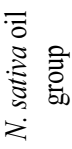 & $\begin{array}{c}\text { Average } \\
\text { Mean } \pm \text { S.D. } \\
\text { Closure time }\end{array}$ & $\begin{array}{l}3.99-9.46 \\
6.56 \pm 0.40\end{array}$ & $\begin{array}{c}3.52-8.06 \\
5.89 \pm 0.38^{*}\end{array}$ & $\begin{array}{c}2.21-5.30 \\
3.91 \pm 0.28^{* *} \\
\text { Day } 20\end{array}$ & $\begin{array}{c}1.43-2.25 \\
1.89 \pm 0.42^{* *} \\
\text { Day } 23\end{array}$ & $\begin{array}{c}0.91-0.99 \\
0.94 \pm 0.25^{* *}\end{array}$ \\
\hline
\end{tabular}

N.B. The mean recorded is the average of 5 measured wound $\left(\mathrm{cm}^{2}\right)$

* Significant $\mathrm{P}<0.005$

**Highly significant $\mathrm{P}<0.001$

The antibiotic treated group was the faster repairing of the wounded skin. The contractile ability began from the first week of treatment. The restricting volumes of the wounds were significantly taster than the control ones. The closure time was between 18 to 22 days and the hairs grew at the fourth week of treatment (Table 1, Plate: 1: 2, 3, 4 and 5). Regarding to the NSO treated group, the contracting ability began from the first week of treatment, however, with slower rate than the antibiotic treated group, but with faster rate than the control group. The closure time was similar to that of the antibiotic group, however, within 20 to 23 days. The hair growing time at the fifth week as well as the skin restore. 


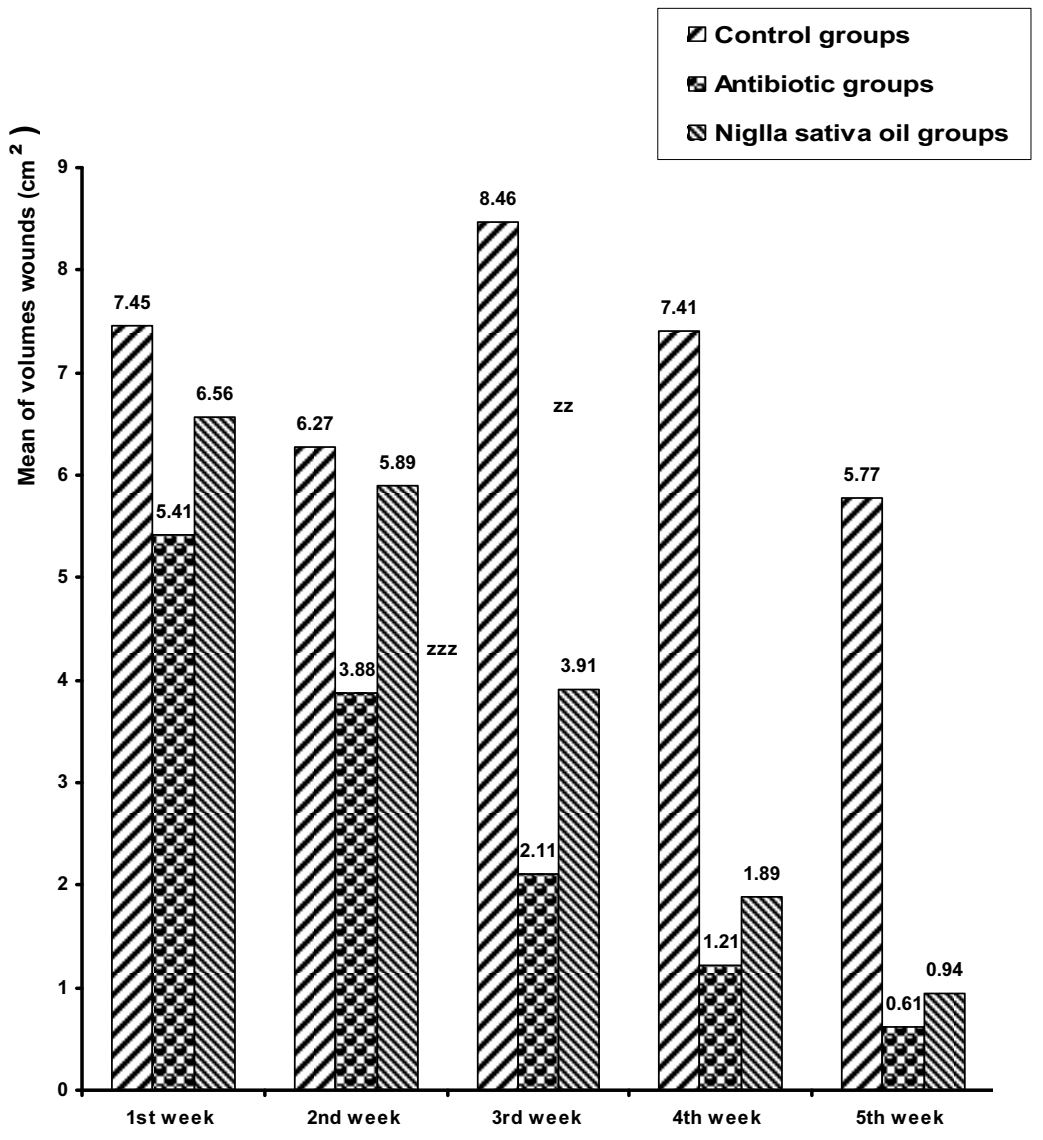

Fig.1. Changes of wound volumes $\left(\mathrm{cm}^{2}\right)$ after topical application of treatmeants till 5 weeks.

\section{Histological Examination}

The burn-wounds of the control groups show certain degeneration of the skin architecture; the epidermis was completely degenerated and the rest of the epidermal cells became necrotic forming a dead layer on the burn. In addition the hair roots also disappeared from the burned skin regions (Plate 2: 6, 7, 8, and 9). The wound appearance of the treated skin burn-wounds restored, and a horny layer above the wound followed by hyperplasia of the epidermal cells appeared thicker than that of control ones. A large number of inflammatory cells were observed to immigrate below the burned epidermis. There was no skin infection of the treated groups. By time the treatment of burned skin by antibiotic or NGO, the periphery of wounds where shown to restore the normal structure and 
some hair roots were also grown. At the end of experiment, the burnwounds which were treated by both antibiotic and oil of NSO slightly restored their normal architectures.

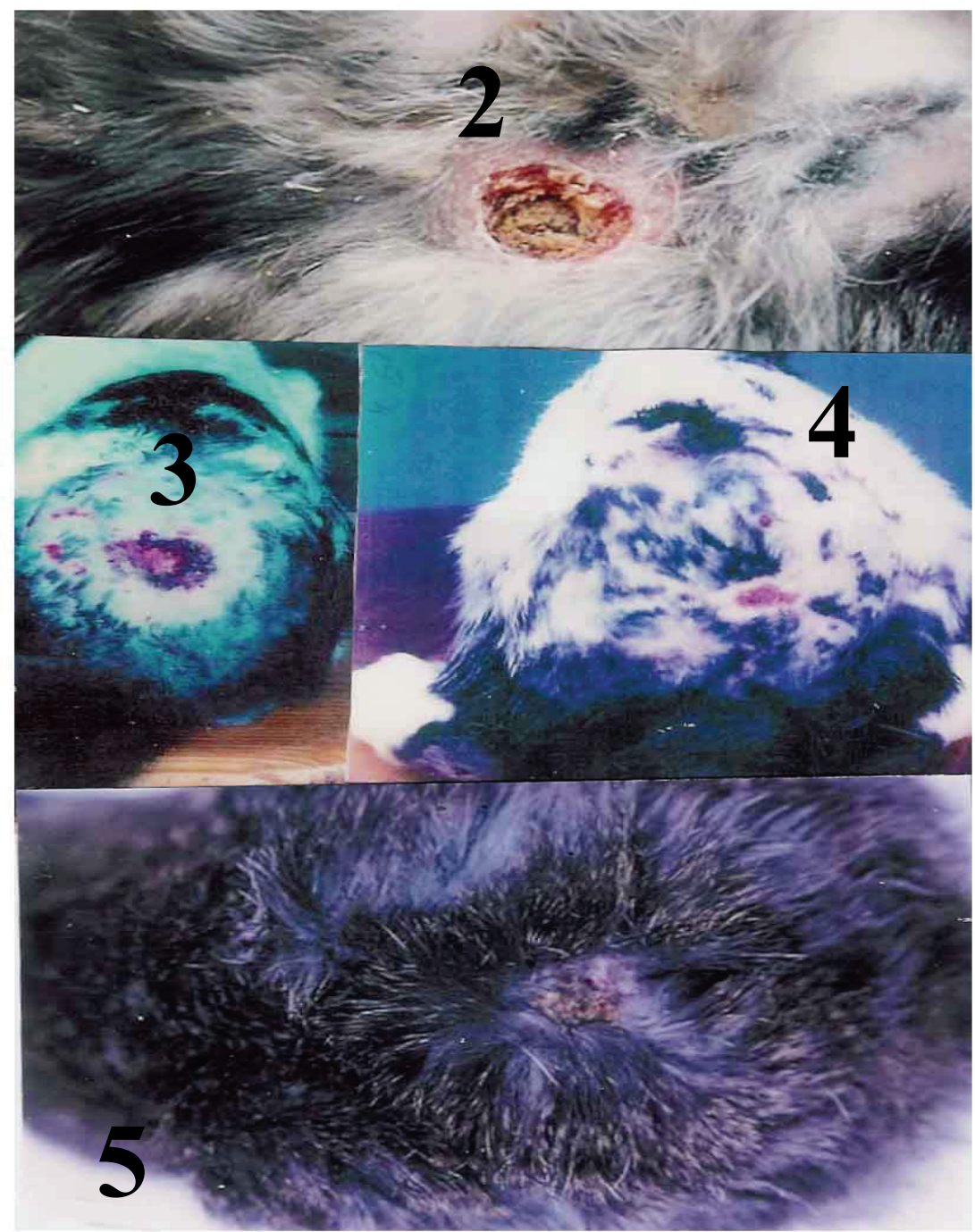

Plate 1. Showing burned skin of rabbits after topical application of treatments, 2: Untreated burned skin, 3 and 4: Treated burned skin by antibiotic Baneocin - Zinc and 5: Treated burned skin by NSO. 


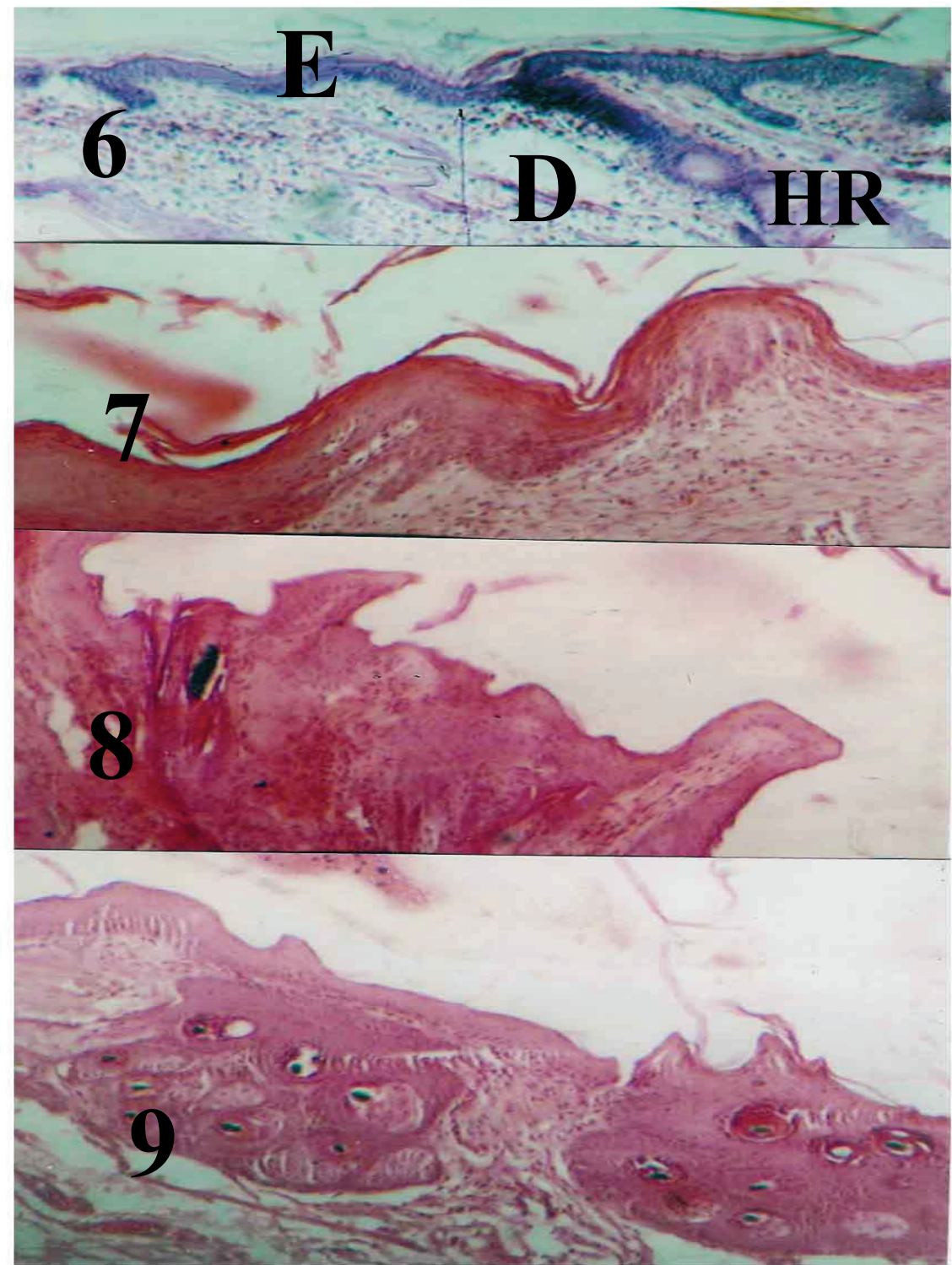

Plate 2. Showing different sections of skin, $6:$ normal skin architecture, epidermis (E), dermis (D) and hair root (HR), 7 : burned skin showing severe destruction of skin structure, 8 : burned skin periphery after treatment by Baneocin - zinc showing hyperplasia, inflammatory cell migration and repairing of hair roots, $9:$ the periphery of burned skin treated by NSO after 5 weeks showing a number of renewed hair roots 


\section{Discussion}

The present study indicated that the closure time of the wounds of both treated animals was more or less similar. However, the hair growing time was the same in both treated groups. Histologically, the peripheries of the wounds grow rapidly in treated groups without any contamination by microbes. The present results support the use of NSO in topical skin care and healing wounds.

Much of the biological activity of the Nigella sativa seeds shown to be due to thymoquinone, the major component of the essential oil. The seeds/oil have anti-inflammatory, analgesic, antipyretic, antimicrobial and antineoplastic activity ${ }^{[18]}$. These multi therapeutic action of Nigella sativa, specially the antimicrobial activity support our results reported here which indicated that topical application of such oil had antimicrobial activity and shown also by application broad spectrum antibiotic in this study (Baneocin zinc).

In this experiment it is well observed that the oil of Nigella sativa has moderately accelerated closure time by giving normal appearance of the burn wounded skin, and enhanced the hair roots growing ${ }^{[1]}$. Herbal drugs were said to be effective in treatment several types of skin ailments such as chronic and gangrenous wounds, cut and blisters due to burns ${ }^{[22]}$.

To investigate the role of NSO in treatment of skin burn wound coverage, we treated the rabbit burned skin two times a day by NSO, by histological examination it was shown that the immune response was enhanced in the form of the presence of large number of inflammatory cells in dermis of the burn-wounds, this may be due to the presence of essential fatty acids which initiate the immune system ${ }^{[14]}$. This opinion was supported by Fararh et al. ${ }^{[7]}$ who treated hamsters with NSO, and found a significant increase of phagocytic activity and phagocytic index of peritoneal macrophages and lymphocyte count in the peripheral blood.

Nigella sativa contains proteins which may stimulate the dermal fibroblast. Phan et al. ${ }^{[17]}$ used extract of plant Chromolaema odorata, herbal to treat soft tissues wounds and skin infection, in order to demonstrate whether the extract increased expression of several components of adhesion complex, and fibronectin by human keratocytes. They showed that such extracts stimulated expression of many proteins which are essential to stabilize epithelium. By this effect, NSO may 
reduce the burn-wounds in the present study. It was indicated that Nigella sativa seeds, extracts, and oil, had antioxidant stress, and exerted a therapeutic action in different studies; preserving pancreatic beta-cell integrity and protect them against oxidative stress ${ }^{[13]}$; decreased the fibrinolytic potential of tumor cells ${ }^{[6]}$. The beneficial effects of the use of such oil might be related to their cytoprotective, antioxidant actions, and in some mediators of inflammation. In conclusion, the using of NSO has gained popularity as ingredients in topical skin care which are supported by the results of the present study. Histological study indicates the improvement in the burn-wounds of rabbit skin by NSO. However, future research works are needed to insure the beneficial usage of such oil in burn wounds treatment.

\section{References}

[1] Ali, B.H. and Blunden, G., Pharmacological and toxicological properties of Nigella sativa, Phytother. Res., 17(4): 299-305 (2003).

[2] Bate, A., Botanical Anti-Aging Skin Care Ingredient Guide; Watercress extract, Academic Press, New York (2007).

[3] Burits, M. and Bucar, F., Antioxidant activity of Nigella sativa essential oil, Phytother. Res., 14(5): 323-328 (2000).

[4] Compes, L.S., Amoros, T.P., Campos, R.M., Delachica, A.M. and Barrios, H.A., Therapeutic uses for Asian yellow flower crowfoot, genus Ranunculus: the case of Blastoes timulina, Rev. Enferm., 28(1): 59-62 (2005).

[5] El-Kadi, A. and Kandil, O., Effects of Nigella sativa (the black seed) on immunity, Proceeding of the $4^{\text {th }}$ International Conference on Islamic Medicine, Kuwait. Bull. Islamic Med., 4: 344-348 (1986).

[6] Ewad, E.M., In vitro decreases of the fibrinolytic potential of cultured human fibrosarcoma cell line, HT 1080, by Nigella sativa oil, Phytomedicine, 12: 100-107 (2005).

[7] Fararh, K.M., Atoi, Y., Shimizu, Y., Shiino, T., Nikomi, H. and Takewaki, T., Mechanisms of the hypoglycaemic and immuno protectiating effects of Nigella sativa L., oil in streptozotocin induced diabetic hamsters, Res. Vet. Sci., 77(2): 123-129 (2004).

[8] Hanafi, M.S. and Hatem, M.F., Studies on the anti-microbial activity of Nigella sativa seed (black cumin), J. Ethnopharmacol., 34: 275-278 (1991).

[9] Haq, A., Abdullatif, M., Lobo, P.I., Khabar, K.S., Sheth, K.V. and Al-Sedairy, S.T., Nigella sativa: Effect on human lymphocytes and polymorphonuclear phagocytic activity, Immunopharmacol., 30(2): 147-150 (1995).

[10] Haq, A., Lobo, O.I., Al-Tufail, M., Roma, N.R. and El-Sedairy, S.T., Immunomodulatory effect of Nigella sativa protein fractionated by ion exchange chromatography, Int. J. Immunopharmacol., 21(4): 283-285 (1999).

[11] Hirasawa, Y., Ori, K., Yamada, T., Ohtsu, S., Matsui, Y., Miwa, Y., Twasaki, S., Shimizu, M., Kyuki, K. and Higo, S., Antiallergic action effect on Pseudolarix amabilis Rehd. Extract and its efficacy on a topic dermatitis. Nippon Yakurigaku Zasshi., 124(4): 271-283 (2004).

[12] Houghton, P.J., Zarka, R., de las Heras, B. and Hoult, J.R., Fixed oil of Nigella sativa and derived thymoquinone inhibit eicosanoid generation in leukocyte and membrane lipid peroxidation, Planta Med. Fed., 61(1): 33-36 (1995). 
[13] Kanker, M., Coskun, O., Korkmaz, A. and Oter, S., Effect of Nigella sativa on oxidative stress and beta cell damage in streptozotocin-induced diabetic rats, Anat. Rec. Adiscov. Mol. Cell Evol. Biol., 279(1): 685-691 (2004).

[14] Louise, F., New organic skin care recipes to treat various burned animals naturally, Online J. MLM.Com., 247(2): (2007).

[15] Mabrouk, G.M., Moselhy, S.S., Zohny, S.F., Ali, E.M., Helal, T.E., Amin, A.A. and Khalifa, A.A., Inhibition of methyl nitrosourea (MNU) induced oxidative stress and carcinogenesis by orally administrated bee honey and Nigella sativa grains in Sprague Dawely rats, J. Exp. Clin. Cancer Res., 21(3): 341-346 (2002).

[16] Nair, SC., Salomi, MJ. and Panikkar, KR., Modulatory effects of Crorcus sativa and Nigella sativa extracts on cisplatin-induced toxicity in mice, J. Ethnopharmacol., 31(1): 7583 (1991).

[17] Phan, T.T., Allen, J., Hughes, M.A., Cherry, G. and Wojnarowska, F., Upregulation of adhesion complex proteins and fibronectin by human keratinocyte treated with an aqueous extract from leaves of Chromolaena odorata. Eur., J. Dermatol., 10(7): 522-525 (2000).

[18] Priya, K.S., Arumugam, G., Rathinam, B., Well, A. and Babu, M., Celosia argental inn. leaf extract improves wound healing in a rat burn-wound model, Wound Repair Regen., 12 (6): 618-625 (2004).

[19] Randhawa, M.A. and El-Ghamdi, M.S., A review of pharmaco therapeutic effect of Nigella sativa, Pakistan J. Med. Res., 41(2): 77-83 (2002).

[20] Salem, M.L. and Hossain, M.S., Protective effect of black seed oil from Nigella sativa against murine cyto megalovirus, Int. J. Pharmacol., 22(9): 729-740 (2000).

[21] Swamy, S.M. and Tan, B.K., Cytotoxic and immuno potentiation effect of ethanolic extract of Nigella sativa L. soods, J. Ethno Pharmacol., 70(1): 1-7 (2000).

[22] Ysrael, M.C., Tonkin herbal drugs: a multidisciplinary approach to development, Clin. Hemorheal., 29: 247-251 (2003). 


\section{استخدام زيت الحبة السوداء لعلاج وشفاء الجروح المحدثة بالحرق الكيميائي في الأرنب كنموذج للجروح الحرقية}

\section{أسامة عبدالله أبو زنادة}

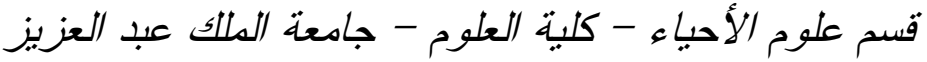
جدة - المعلكة العربية السعودية

الدستخلص. تهذف هذه الدراسة إلى تقييم فاعلية زيت الحبة السوداء في شفاء و إعادة بناء الجروح الحرقية المحدثة كيميائيًا في في لئي

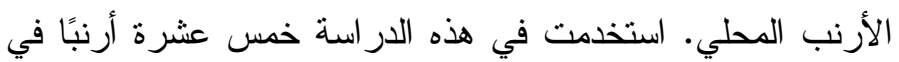

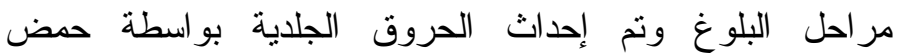

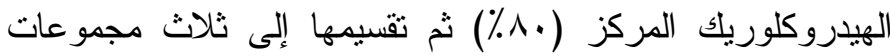

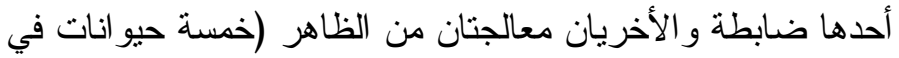

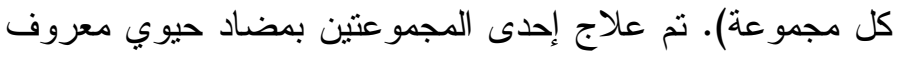

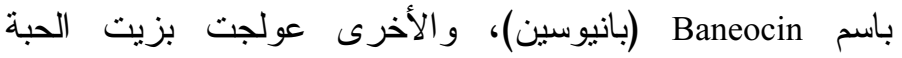

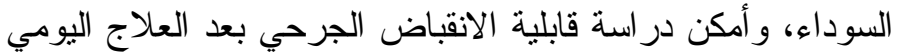

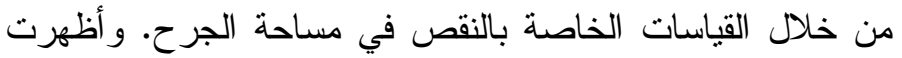

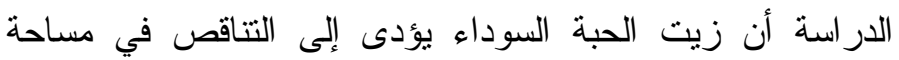

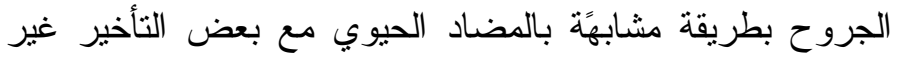

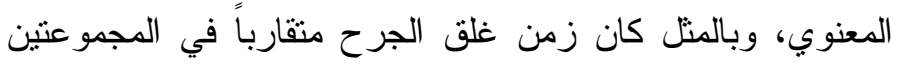

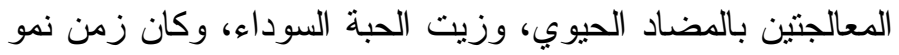

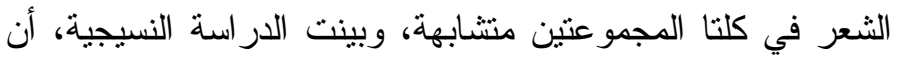

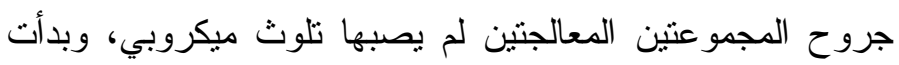

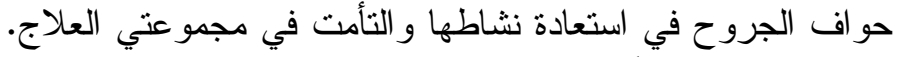

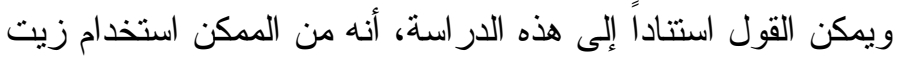

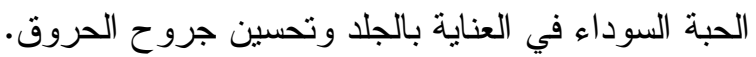

